\title{
The Role of Endotoxin in Protection of Adult Rats from Oxygen-Induced Lung Toxicity
}

\author{
LeE Frank, John Yam, and Robert J. Roberts, Departments of Pediatrics and \\ Pharmacology, The Toxicology Center, The University of Iowa, Iowa City, \\ Iowa 52242
}

\begin{abstract}
A B S T RAC T Adult rats show evidence of severe lung damage after $72 \mathrm{~h}$ of continuous exposure to hyperoxia $\left(96-98 \% \mathrm{O}_{2}\right)$. Treatment of adult rats with a solution of Plasmanate, inadvertently contaminated with endotoxin-producing organisms, or with purified endotoxin itself markedly altered the lung toxicity associated with hyperoxic exposure (survival in treated animals $=110 / 113[97 \%]$ versus survival in untreated animals $=56 / 172[33 \%]$ ). After $72 \mathrm{~h}$ of hyperoxic exposure, the endotoxin-treated rats demonstrated significant increases in lung superoxide dismutase, catalase, and glutathione peroxidase activity, a protectant enzyme response not seen in untreated adult rats. The basis for endotoxin's protective effect from hyperoxic lung damage is believed to be related to the stimulated increase in activity of the pulmonary antioxidant enzyme defense system. Some previously known actions of endotoxin are speculated to also serve a protective function by opposing some of the usual detrimental effects of high concentrations of $\mathrm{O}_{2}$ on the lung.
\end{abstract}

\section{INTRODUCTION}

Although the potential toxic consequences of prolonged hyperoxic therapy are appreciated by most clinicians, there are many situations in which such treatment is mandatory, particularly in the treatment of the neonate. Circumvention of the toxic effects of oxygen on the lung may be possible if the mechanism of oxygen-induced pulmonary damage were elucidated. One theory of the mechanism of oxygen-induced pulmonary toxicity, advanced by Gerschman in the early 1960's, has received recent experimental support (1-3). This is the so-called "free radical theory" of $\mathrm{O}_{2}$ toxicity which attributes the damaging effects of hyperoxia to the various highly reactive metabolites of molecular $\mathrm{O}_{2}$ which

John Yam is a Proctor and Gamble predoctoral fellow.

Received for publication 13 June 1977 and in revised form 30 September 1.977. are formed in the cell during the course of many biological reactions (1-3). Under conditions of hyperoxia, the generation of these cytotoxic products of $\mathrm{O}_{2}$ is believed to increase markedly (4). Many laboratories, including our own, have reported on the probable importance of the pulmonary antioxidant enzyme systems including superoxide dismutase (SOD), ${ }^{1}$ the glutathione system, and catalase, in protecting the cells of the lung from oxygen-free radical injury (5-9).

In immature animals, there is a rapid increase in pulmonary SOD activity on exposure to hyperoxia, whereas in the lungs of adult animals this rapid protective enzyme response with similar exposure to toxic levels of $\mathrm{O}_{2}$ does not occur (7-9). The increase in the lung complement of this protective enzyme and the increase in activity of other cooperative antioxidant systems in the lung (glutathione, glutathione peroxidase, glutathione reductase, catalase) has been postulated as a possible explanation for the well-known tolerance of the immature animal to hyperoxic challenge compared to the adult animal $(8,9)$.

During the course of studies involving long-term hyperoxic exposure of adult rats, it was observed that a group of adult animals who had received injections of a commercial blood product (Plasmanate, Cutter Laboratories, Inc., Berkeley, Calif.) all survived a usually lethal $72 \mathrm{~h}$ exposure to $96-98 \% \mathrm{O}_{2}$ without signs or symptoms of respiratory distress or lung pathology. It was later discovered that the Plasmanate used had been inadvertently contaminated in our laboratory with bacteria (Staphylococcus epidermidis and two Pseudomonas species). ${ }^{2}$ These

\footnotetext{
${ }^{1}$ Abbreviations used in this paper: CP, contaminated Plasmanate; CP filtrate, CP after passage through Millipore filter to remove bacteria; SOD, superoxide dismutase.

${ }^{2}$ The original bottle of contaminated Plasmanate which initiated these investigations was contaminated in our laboratory. Repeated assays for the presence of endotoxin or bacteria in newly opened bottles of Plasmanate have been consistently negative.
} 
initial observations and the subsequent studies identifying bacterial lipopolysaccharide (endotoxin) as the probable active agent responsible for the marked protective effect against pulmonary $\mathrm{O}_{2}$ toxicity form the basis for this report.

\section{METHODS}

Rats employed in these experiments were Sprague-Dawley albino rats $(200-250 \mathrm{~g})$ obtained from Bio-Lab Corp. (St. Paul, Minn.) and maintained on standard laboratory pellets and water ad libitum.

Exposures to $21 \%$ and $96-98 \% \quad \mathrm{O}_{2}$ were conducted under carefully monitored conditions as described in detail $(7,8)$. For the initial experiments, adult rats were treated with i.p. injections at times $0\left(2.0 \mathrm{~cm}^{3}\right), 24 \mathrm{~h}\left(1.5 \mathrm{~cm}^{3}\right)$, and 48 $\mathrm{h}\left(1.5 \mathrm{~cm}^{3}\right)$ into the exposure period, and sacrificed at the end of $72 \mathrm{~h}$. Injection solutions consisted of one of the following: sterile saline; $5 \%$ bovine albumin (Sigma Chemical Co., St. Louis, Mo.) in saline; fresh or frozen rat plasma; Plasmanate (Human Protein Fraction, 5\%-Cutter Laboratories, Inc., Berkeley, Calif.); Plasmanate innoculated with a bacterial culture (S. epidermidis and two Pseudomonas species) and referred to herein as contaminated Plasmanate (CP); sterile filtrate obtained by passing $\mathrm{CP}$ through a Millipore filter (Millipore Corp., Bedford, Mass.) $(45 \mu \mathrm{M})$; diluted Plasmanate (1:10 in sterile saline) containing the live bacteria gathered from the Millipore filters; and $\mathrm{CP}$, to which gentamicin $(15 \mu \mathrm{g} / \mathrm{ml})$ had been added to kill the bacteria. For the later studies with bacterial lipopolysaccharides (endotoxin), rats received daily i.p. injections of either Escherichia coli 0111:B4 or Salmonella typhimurium lipopolysaccharide (Sigma Chemical Co.) diluted in sterile saline. Dosages varied with the individual experiments (see Results).

At the end of the $72 \mathrm{~h}$ exposure period, all the rats were observed in room air for $1-2 \mathrm{~h}$ to assess the degree of respiratory distress and cyanosis out of the $96-98 \% \mathrm{O}_{2}$ environment. The survival totals for each treatment group were recorded at the end of this air challenge period and the survivors were sacrificed by decapitation. The lungs were perfused via the pulmonary artery with ice-cold isotonic buffer (potassium phosphate $0.1 \mathrm{M}, \mathrm{KCl} 0.15 \mathrm{M}, \mathrm{pH} 7.4$ ), and were then homogenized for $2 \mathrm{~min}$, in the cold, in a Sorvall Omnimixer (Sorvall, Ivan, Inc., Norwalk, Conn.) with a 10:1 (vol:W) solution of potassium phosphate buffer, $0.005 \mathrm{M}, \mathrm{pH}$ 7.8 , for the homogenization. The homogenates were assayed immediately after preparation for SOD activity by the standard ferricytochrome $c$ assay (5). Lung glutathione peroxidase activity (using cumene peroxide as substrate) and Cat activity were determined on 15,000 $\mathrm{g}$ homogenized supernate according to the methods described by Paglia and Valentine (10), and by Holmes and Masters (11), respectively. DNA analysis was done according to the method of Richards (12). Lung enzyme activities were expressed on a per lung basis as percent of control (air-exposed) lung values.

Supplies of CP were maintained by aseptically transferring by syringe $0.25 \mathrm{~cm}^{3}$ of the contents of the original contaminated bottle of solution to fresh $\left(250 \mathrm{~cm}^{3}\right)$ bottles of Plasmanate, and allowing these inoculated bottles to incubate at room temperature for $2 \mathrm{wk}$ or more before use. Microbiological studies were performed by the Medical Microbiology Laboratory, The University of Iowa Hospitals and Clinics. All filtrates obtained by Millipore filtration of the $\mathrm{CP}$ (CP filtrates) were checked by routine culture procedures and found to be bacteria-free.

The presence of endotoxin in the $\mathrm{CP}$ and $\mathrm{CP}$ filtrates was tested for by the lead acetate assay in rats (13), the epinephrine skin test in rabbits (14), and the rabbit pyrogen assay (15). For all these bioassays, $0.25 \mathrm{~cm}^{3}$ of CP filtrate was injected as the test solution and $0.25 \mathrm{~cm}^{3}$ of fresh Plasmanate used for the control injections. The limulus amoebocyte lysate assay (E-Toxate, Sigma Chemical Co.) was also used for purposes of quantitating the amount of endotoxin present in the various injection solutions (16). The tissue for pathological study was obtained from air and $\mathrm{O}_{2}$-exposed animals immediately after sacrifice. Lung fixation was done using $10 \%$ buffered formalin solution instilled via tracheal cannula from a reservoir bottle of fixative elevated $25 \mathrm{~cm}$ above the level of the lung. The lungs were also perfused with the same fixative via the pulmonary artery. Hematoxylin and eosin were used for staining. The number of alveolarfree mononuclear cells and macrophages were determined on randomly selected and coded slides using high dry power $(\times 450)$ and oil immersion $(\times 1,000) .10$ high power fields per slide were randomly selected with the criteria being that the microscopic field encompassed by the counting grid show nonatalectatic alveoli and no large blood vessels. Erythrocytes and polymorphonuclear cells were not counted. We chose to conservatively label cells as "macrophages" when they met all the morphological criteria suggested in the text and illustrations of Myrvik et al. (17).

Statistical analyses were done using the Student's group $t$ test and the nonparametric Fisher exact probability test utilizing a significant level of $P<0.01$.

\section{RESULTS}

The survival data for all the adult rats exposed to $96-98 \% \mathrm{O}_{2}$ for a $72 \mathrm{~h}$ period are shown in Fig. 1. A total of 153 adult rats were used in these experiments as controls to determine the normal tolerance of these animals to hyperoxia. 47 rats (31\%) survived the 3 day exposure and all but three of these survivors were observed to be in marked respiratory distress (labored respirations with abdominal and (or) thoracic retrac-

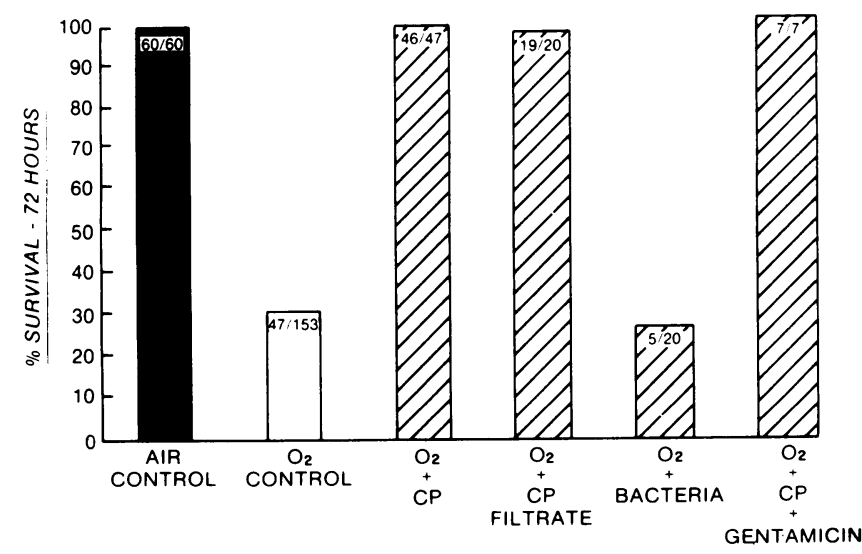

FIgURE 1 Alteration of oxygen-induced lethality in adult rats. Percent survival after $72 \mathrm{~h}$ of continuous exposure to $96-98 \% \quad \mathrm{O}_{2}$ is plotted for the various treatment groups as described in the text. Bacteria = organisms eluted from Millipore filter after CP passage; gentamicin $(15 \mu \mathrm{g} / \mathrm{ml})$ added to CP for the last treatment group illustrated). Numbers indicate number of survivors/number in group. 
tions, cyanosis, and lethargy) when placed in room air. At autopsy these $\mathrm{O}_{2}$-exposed control rats had marked pulmonary edema with scattered areas of the lung surface showing evidence of hemorrhage. $5-10 \mathrm{~cm}^{3}$ of serous fluid was usually present in the thoracic cavity. Survival of rats in $\mathrm{O}_{2}$ was statistically no different whether they had received i.p. injections of saline $(12 / 51)$ or a protein-containing solution: rat serum (16/40), 5\% albumin (8/19), or fresh Plasmanate (11/43). All the air-control animals (60/60) receiving these same daily injections survived with no abnormal lung findings at autopsy. Of the rats treated with $\mathrm{CP}$ injections, 46 out of $47(98 \%)$ survived the same $72 \mathrm{~h}$ hyperoxic exposure period. Approximately $10 \%$ of these survivors showed mild signs of respiratory distress with slightly labored respirations when placed in room air and observed side by side with air controls. Only two of the 46 survivors had gross autopsy evidence of pulmonary edema with fluid in the thoracic cavity. Of the $20 \mathrm{O}_{2}$-exposed rats treated with the CP filtrates, 19 survived without evidence of pulmonary edema. In contrast, only five of 20 rats injected with the live bacteria obtained from the CP survived the hyperoxic exposure and all showed lung changes similar to the $\mathrm{O}_{2}$ control rats. All seven of the rats who received the $\mathrm{CP}$ which was pretreated with bactericidal levels of gentamicin to kill the bacteria survived $\mathrm{O}_{2}$ exposure without gross evidence of lung damage. The results with these last three groups tended to rule out live bacteria as the protectant agent. Survival totals for all the CP-treated groups compared to the $\mathrm{O}_{2}$ controls were significantly different $(P$ $<0.01)$.

Histologically, the lungs of the control $\mathrm{O}_{2}$-exposed rats showed scattered areas of hemorrhage and alveolar, interstitial, and perivascular edema. There was generalized thickening of the alveolar septa due to edema and hypercellularity, and the alveoli contained debris, many free mononuclear cells and macrophages, and occasional polymorphonuclear cells. The lungs of the $\mathrm{CP}$-treated $\mathrm{O}_{2}$-exposed rats did not show the marked edema and hemorrhage observed in the $\mathrm{O}_{2}$ controls. Instead, only focal areas of thickened alveolar septa were observed, representing minimal focal edema or hypercellularity. Some of the lungs examined had rare small areas of alveolar hemorrhage. The thin, lace-like alveolar pattern seen in the normal airexposed lungs was essentially maintained in the CPtreated $\mathrm{O}_{2}$-exposed rats. The number of alveolar-free mononuclear cells observed in the $\mathrm{O}_{2}$-exposed $\mathrm{CP}$ treated rat lungs $(36 \pm 2$ cells/10 random high power fields per slide) was no different than in the air control lungs $(33 \pm 3)$, and significantly less $(P<0.01)$ than the number of cells consistently observed in the untreated $\mathrm{O}_{2}$ control rat lungs $(86 \pm 11)$. For alveolar-free cells meeting all the morphological criteria for macrophages, the respective number of cells counted/ 10 high power fields per slide were $13 \pm 1$ (air-control), $14 \pm 1\left(\mathrm{O}_{2}, \mathrm{CP}\right.$-treated$)$, and $32 \pm 4\left(\mathrm{O}_{2}\right.$ control $)(P$ $<0.01)$. There was no histological evidence by gram stain of bacterial infection in the lungs of the CPtreated or control rats.

Lung weight/body weight ratios of the experimental rats were calculated as another index of the degree of pulmonary edema resulting from hyperoxic exposure. The air controls had a mean ratio of $0.47 \pm 0.01 \%$, the control $\mathrm{O}_{2}$ rats a mean ratio of $0.78 \pm 0.02 \%$ ( $167 \%$ of the air control value), and the $\mathrm{CP}$-treated $\mathrm{O}_{2}$-exposed rats a mean ratio of $0.60 \pm 0.02 \%$ (129\% of the air control value). These ratios were all statistically different from one another $(P<0.01)$. Thus, by this parameter, the $\mathrm{CP}$-treated $\mathrm{O}_{2}$-exposed rats did have evidence of increased lung weight even though edema was not grossly identified. However, if total pulmonary edema is considered as the sum of pleural effusion and lung edema fluid $(18,19)$, then the lung weight/ body weight ratio for the $\mathrm{O}_{2}$-exposed control rats, with an average pleural fluid volume of $7.0 \mathrm{~cm}^{3}$, would, in fact, be $\cong 4.50 \%$, or nearly $1,000 \%$ of the air control value. The degree of protection from $\mathrm{O}_{2}$ induced edema formation provided by the $\mathrm{CP}$ treatment is thus considerable.

Fig. 2 shows the results of SOD enzyme analysis of the control and CP-treated lungs after $72 \mathrm{~h}$ of hyperoxic exposure. Expressed as percent of the air control values and based on either units of activity per gram lung, units per whole lung, or units per milligram DNA, there are significant increases in SOD activity in the $\mathrm{CP}$-treated $\mathrm{O}_{2}$-exposed rat lungs compared to the air and to the $\mathrm{O}_{2}$ controls $(P<0.01)$. The

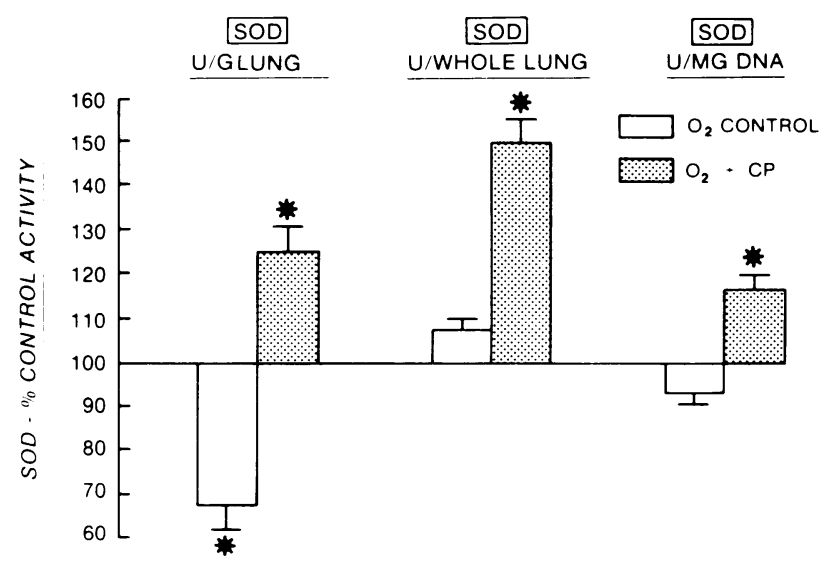

Figure 2 Oxygen-induced changes in lung SOD activity. $\mathrm{O}_{2}$ control (saline) and $\mathrm{O}_{2}$ plus CP-treated rats exposed to $96-98 \% \mathrm{O}_{2}$ for $72 \mathrm{~h}$. SOD calculated as units of activity per gram lung, per whole lung, and per mg DNA and expressed as percentage of control (air-exposed rat lung) SOD activity. Bars represent SEM. ${ }^{*} P<0.01$ compared to SOD activity of air-exposed control lungs. 
TABLE I

Lung Antioxidant Enzyme Activities after $72 \mathrm{H}$ of Exposure to $96-98 \% \mathrm{O}_{2}{ }^{*}$

\begin{tabular}{lccc}
\hline & SOD & Glutathione peroxidase & Catalase \\
\hline Ullung & $\begin{array}{c}\mu \text { mol NADPH } \\
\text { oxidized/min/lung }\end{array}$ & IU/lung $\$$ \\
Air-control & $842 \pm 48(100)$ & $8.89 \pm 0.45(100)$ & $1,917 \pm 79(100)$ \\
$\mathrm{O}_{2}$-control & $884 \pm 50(105)$ & $10.32 \pm 0.78(116)$ & $2,277 \pm 65(119)^{\sharp \prime}$ \\
$\mathrm{O}_{2}+\mathrm{CP}$ & $1,190 \pm 38(141) \S$ & $11.32 \pm 0.44(127)^{\| \prime}$ & $2,768 \pm 132(144) \S$ \\
\hline
\end{tabular}

* Enzyme activities expressed on per lung basis and represent values determined from 6-11 experimental animals for each group. Number in parentheses $=$ percent of air-control enzyme activity.

$11 \mathrm{IU}$ is defined as the amount of enzyme which reacts with $1 \mu \mathrm{mol}$ of $\mathrm{H}_{2} \mathrm{O}_{2}$ per minute.

$\$ P<0.01$ compared to both air-control and $\mathrm{O}_{2}$-control groups.

" $\boldsymbol{P}<0.01$ compared to air-control group.

marked disparity in SOD activity between the CPtreated and untreated groups when expressed as units per gram lung reflects the large amount of nonSOD-containing serous edema fluid in the $\mathrm{O}_{2}$ control animal lungs.

Results of preliminary studies of glutathione peroxidase and catalase activities in lung tissue from some of the same experimental animals are shown in Table $I$. $\mathrm{CP}$-treated $\mathrm{O}_{2}$-exposed animals had significant increases in all the antioxidant enzymes in these experiments $(P<0.01)$, whereas the $\mathrm{O}_{2}$ control rat lungs had a significant increase only in catalase activity.

All the bioassays used to test for the presence of endotoxin in the CP and CP filtrates gave positive results (Table II). The limulus amoebocyte lysate assay performed with sequential dilutions of CP filtrate and known concentrations of commercial $E$. coli endotoxin indicated that the CP filtrate contained the equivalent of $\cong 1-5 \mathrm{mg} / \mathrm{ml}$ of bacterial endotoxin.
Table III shows the survival data from two experiments using treatments with commercially available endotoxins (E. coli 0111:B4 and Salmonella typhimurium ) in place of CP. Altogether, 38/39 endotoxintreated rats survived the $72 \mathrm{~h}$ hyperoxic exposure compared to $9 / 19$ control adult rats for these two experiments $(P<0.01)$. All the surviving $\mathrm{O}_{2}$ controls had respiratory distress with gross evidence of pulmonary edema with or without hemorrhage. Pulmonary edema was seen in the $\mathrm{O}_{2}$-exposed endotoxin-treated animals only in the lowest endotoxin dose range $(2 \mu \mathrm{g} / \mathrm{kg}$ per day). Some of the rats who received the highest daily doses of endotoxin $(1,900-2,000 \mu \mathrm{g} / \mathrm{kg}$ per day) had several areas of hemorrhage $>5 \mathrm{~mm}$ in their lungs, suggesting that despite protection from $\mathrm{O}_{2}$ lethality, a toxic dose of endotoxin was approached in these rats. Maximal protection without any suggestion of pulmonary toxicity appeared to be within the endotoxin dosage range of $100-1,000 \mu \mathrm{g} / \mathrm{kg}$ per day. Lung SOD activity in the endotoxin-treated rats (calculated on a per lung basis and expressed as percent of air-control activity) was significantly increased $(155.4 \pm 4.5 \%)$ $(P<0.01)$ compared to the air-control and $\mathrm{O}_{2}$-control (111.4 $\pm 5.9 \%)$ enzyme values.

\section{DISCUSSION}

The results of many recent studies support the hypothesis that increased pulmonary levels of the protective antioxidant enzymes are correlated with increased survival in hyperoxia $(6,9,20)$. These enzyme systems perform the vital function of detoxifying the increased flux of cytotoxic-free radical products of $\mathrm{O}_{2}$ formed during hyperoxic exposure. Adult rats have been repeatedly shown to be intolerant of exposure to $95^{+\%} \quad \mathrm{O}_{2}$ for $>72 \mathrm{~h}$, manifesting severe and

TABLE II

Bioassays for Presence of Endotoxin in CP Filtrates*

\begin{tabular}{|c|c|c|}
\hline Bioassay $\ddagger$ & Animal & Results $\S$ \\
\hline Lead acetate test & Rat & $\begin{array}{c}\text { Mortality: } 80 \% \text { with lead acetate }(5 \mathrm{mg}) \text { plus CP filtrate }\left(0.25 \mathrm{~cm}^{3}\right) \\
0 \% \text { with lead acetate plus fresh Plasmanate }\left(0.25 \mathrm{~cm}^{3}\right) \\
0 \% \text { with lead acetate or CP filtrate alone }\end{array}$ \\
\hline Epinephrine skin test & Rabbit & $\begin{array}{l}\text { Positive skin test (intradermal hemorrhage } \geq 1 \mathrm{~cm} \text { ) with all } \\
\text { dilutions of CP filtrate used (up to 1:500). } \\
\text { Negative test with fresh Plasmanate. }\end{array}$ \\
\hline Pyrogen test & Rabbit & $\begin{array}{l}\text { Positive biphasic fever response in } 75 \% \text { of test animals; uniphasic } \\
\text { fever curve in remaining } 25 \% \text {. }\end{array}$ \\
\hline
\end{tabular}

* CP filtrate = contaminated Plasmanate passed through Millipore filter $(45 \mu \mathrm{m})$ to remove bacteria (S. epidermidis and Pseudomonas species).

$\$$ Test details referenced in Methods.

$\S$ When these bioassays were repeated using Plasmanate contaminated only with $S$. epidermidis the tests were all negative. When Plasmanate contaminated with only the Pseudomonas species was used, all the tests were positive. 
TABLE III

Comparison of Control and Endotoxin Treated Adult Rats after $96-98 \% \mathrm{O}_{2}$ Exposure for $72 \mathrm{H}$

\begin{tabular}{|c|c|c|c|}
\hline \multirow[b]{2}{*}{ Treatment } & \multirow[b]{2}{*}{$\begin{array}{l}\text { Control } \\
\text { (saline) }\end{array}$} & \multicolumn{2}{|c|}{ Endotoxin treated } \\
\hline & & $\begin{array}{c}\text { E. coli } \\
\text { 0111:B4 }\end{array}$ & $\begin{array}{c}S . \\
\text { typhimurium }\end{array}$ \\
\hline $\begin{array}{c}\text { Average dose } \\
\mu \mathrm{g} / \mathrm{kg} / \mathrm{day}{ }^{*}\end{array}$ & & 800 & 800 \\
\hline Survival, \% & $9 / 19(47 \%)$ & $15 / 15(100 \%) \downarrow$ & $23 / 24(96 \%)$ \\
\hline $\begin{array}{l}\text { Pulmonary } \\
\text { edema } \$\end{array}$ & $19 / 19(100 \%)$ & $1 / 15(7 \%) \downarrow$ & $4 / 24(17 \%) \ddagger$ \\
\hline $\begin{array}{l}\text { Pulmonary } \\
\text { hemorrhage" }\end{array}$ & $17 / 19(89 \%)$ & $3 / 15(20 \%) \downarrow$ & $7 / 24(29 \%) \ddagger$ \\
\hline
\end{tabular}

* Average dose obtained by totalling the dosages received by all the animals in each dosage subgroup for $E$. coli $(1,900,450$, and 100 $\mu \mathrm{g} / \mathrm{kg}$ per day) and for Salmonella endotoxin $(2,000,1,100,125$, and 1 $\mu \mathrm{g} / \mathrm{kg}$ per day) and dividing this figure by total number of experimental animals receiving the treatment.

$\$$ Significantly different from the $\mathrm{O}_{2}$-control (saline) group $(P<0.01)$. $\S$ For endotoxin-treated groups pulmonary edema (fluid in thoracic cavity) was confined to rats in the lowest dosage group ( $1 \mu \mathrm{g} / \mathrm{kg}$ per day).

"For endotoxin-treated groups pulmonary hemorrhage was seen only in animals in the lowest dosage group ( $1 \mu \mathrm{g} / \mathrm{kg}$ per day) and in the highest dosage group $(1,900,2,000 \mu \mathrm{g} / \mathrm{kg}$ per day).

frequently fatal lung damage by the end of such a hyperoxic exposure period. In the adult rat, the activities of the pulmonary antioxidant enzyme systems remain essentially unchanged during the time the toxic lung changes in $95^{+} \% \mathrm{O}_{2}$ are occurring (9). Immature rats, on the other hand, show rapid increases in the protective enzyme activities and a marked tolerance to similar hyperoxic challenge $(7-9,20)$. In the present study we have demonstrated that treatment of adult rats with a plasma protein solution contaminated with bacterial products (CP and CP filtrate) or treatment with purified bacterial lipopolysaccharide (endotoxin) results in a marked change in the susceptibility of adult rats to hyperoxia. Survival after 3 days in $95^{+} \%$ $\mathrm{O}_{2}$ was increased from $33(56 / 172)$ to $97 \%(110 / 113)$ and lung damage in the surviving animals treated with endotoxin was markedly ameliorated. Concomitantly, endotoxin-treated adults demonstrated significantly increased activities of the antioxidant pulmonary enzymes tested, reinforcing the vital role of these antioxidant systems in protection from oxygeninduced lung injury (4-9).

In addition to this new finding of an increase in pulmonary protective enzyme activities stimulated by concurrent treatment with hyperoxia plus endotoxin, we can speculate that some of the previously known biological actions of endotoxin might be important in explaining its demonstrated protective effect against high $\mathrm{O}_{2}$-induced lung injury. For example, the fewer alveolar-free mononuclear cells and macrophages ob- served in the lungs of the endotoxin-treated rats compared to the $\mathrm{O}_{2}$ control lungs (two to threefold difference) was a consistent histological finding in these studies. Although alveolar macrophages are traditionally thought of as repair cells, in the hyperoxic situation it seems feasible to view the macrophage as a potentially harmful influence. High concentrations of oxidant agents are known to drastically affect the bactericidal capabilities of the macrophage and to allow the release of lysosomal enzymes from the altered macrophage (21-24). In addition, recent evidence suggests that cell membrane generated cytotoxic $\mathrm{O}_{2}$-free radicals may also be released $(25,26)$. The release of these potentially cytotoxic agents from the macrophages could, in turn, be responsible for further insult to the adjacent alveolar epithelium and to the surface active material lining the alveoli. The reported effects of endotoxin on the reticuloendothelial cell system and on macrophages in particular $(27,28)$ may explain our finding of an apparent decreased number of macrophages in the alveolar spaces, and a reduction of this potential source of lung insult to the hyperoxia-stressed alveolar lining cells.

Considering other possible mechanisms of endotoxin action, the reported capability of small doses of endotoxin to cause a prolonged vascular hyporeactivity to pressor stimuli $(29,30)$ may serve to reverse or prevent some of the detrimental hemodynamic and perfusion effects known to result from the vasoactive influence of hyperoxia (31-33). Endotoxin might also be acting similar to several other specific agents (oleic acid [34], alpha naphthylthiourea [35], and diphosgene [36]), which cause an initial low-grade toxic insult to the lung and result in a prolongation of survival of animals on subsequent exposure to hyperoxia. The mechanism to explain this phenomenon is not known, but the early stimulation of repair processes by replacement of certain lung cells (membranous Type I) with cells more inherently resistant to $\mathrm{O}_{2}$ (granular Type II) is a possible explanation (37). Finally, there are several reports which indicate that endotoxin is able to stimulate RNA and DNA synthesis in certain animal cells $(38,39)$, an effect that, if generalized, could oppose the known inhibitory action of hyperoxia on nucleotide synthesis which occurs within $24 \mathrm{~h}$ of $\mathrm{O}_{2}$ exposure (40). Thus, in addition to its observed stimulatory effect on lung antioxidant enzyme activity, the marked protective effect of endotoxin observed in our treated adult rats could involve some or all of these other proposed actions of endotoxin in the lung. Further investigations into these possible mechanisms are being undertaken.

In addition to the protective action of exogenous endotoxin, it would be of great interest to obtain epidemiologic evidence for the role of endogenous endotoxin in affecting the lung toxicity associated 
with prolonged $\mathrm{O}_{2}$ therapy in clinical situations in which respiratory insufficiency and gram-negative infection occur concurrently. For example, the incidence of progression of $\mathrm{O}_{2}$-treated hyaline membrane disease to the chronic condition of lung disease in infancy referred to as bronchopulmonary dysplasia, may be altered when gram-negative infection is also present during the period of high $\mathrm{O}_{2}$ treatment for the initial respiratory condition.

In conclusion, treatment of adult rats with an endotoxin-containing solution (CP) and with purified endotoxin has resulted in a marked decrease in their usual susceptibility to hyperoxic lung toxicity, and, concomitantly, a significant increase in the activity of their lung antioxidant enzyme systems. The protection from $\mathrm{O}_{2}$ toxicity afforded by the endotoxin doses employed in these studies may thus be related to the stimulated increase in these lung biochemical defenses and (or) with the hemodynamic, immunologic, and (or) other alterations endotoxin is capable of producing in the animal lung.

\section{ACKNOWLEDGMENTS}

The authors wish to extend their thanks to Dr. William Johnson of the Department of Microbiology, The University of Iowa for his many useful suggestions and to Dr. Thomas Shires of the Departments of Pharmacology and Pathology, The University of Iowa for his assistance with the microscopic analysis. We wish to acknowledge the fine technical assistance provided by Mrs. Mary Jo Kline and Mrs. Diane Lilleg.

This research work was supported by U. S. Public Health Service grant GM 12675, Clinical Pharmacology training grant 1F 32 HL 05415, and Health Profession special project grant 07-D-000008-05.

\section{REFERENCES}

1. Gerschman, R. 1964. Biological effects of oxygen. In Oxygen in the Animal Organism. F. Dickens and E. Neil, editors. Macmillan, Inc., New York. 475-494.

2. Clark, J. M., and C. J. Lambertsen. 1971. Pulmonary oxygen toxicity: a review. Pharmacol. Rev. 23: 37-133.

3. Feeney, L., and E. R. Berman. 1976. Oxygen toxicity: membrane damage by free radicals. Invest. Ophthalmol. 15: 789-792.

4. Fridovich, I. 1974. Superoxide dismutases. Adv Enzymol. Relat. Areas Mol. Biol. A. Meister, editor. John Wiley and Sons, Inc., New York 41: 35-97.

5. McCord, J. M., and I. Fridovich. 1969. Superoxide dismutase: an enzymic function for erythrocuprein (hemocuprein). J. Biol. Chem. 244: 6049-6055.

6. Crapo, J. D., and D. F. Tierney. 1974. Superoxide dismutase and pulmonary oxygen toxicity. Am. J. Physiol. 226: $1401-1407$.

7. Autor, A. P., L. Frank, and R. J. Roberts. 1976. Developmental characteristics of pulmonary superoxide dismutase: relationship to idiopathic respiratory distress syndrome. Pediatr. Res. 10: 154-158.

8. Frank, L., A. P. Autor, and R. J. Roberts. 1977. Oxygen toxicity and hyaline membrane disease: the effect of hyperoxia on pulmonary superoxide dismutase activity and the mediating role of plasma or serum. J. Pediatr. 90: $105-110$.

9. Yam, J., L. Frank, and R. J. Roberts. 1977. Oxygen toxicity: comparison of lung biochemical responses in neonatal and adult rats. Pediatr. Res. In press.

10. Paglia, D. E., and W. N. Valentine. 1967. Studies on the quantitative and qualitative characterization of erythrocyte glutathione peroxidase. J. Lab. Clin. Med. 70: 158-169.

11. Holmes, R. S., and C. J. Masters. 1970. Epigenetic interconversions of the multiple forms of mouse liver catalase. FEBS. (Fed. Eur. Biochem. Soc.) Lett. 11: 45-48.

12. Richards, G. M. 1974. Modifications of the diphenylamine reaction giving increased sensitivity and simplicity in the estimation of DNA. Anal. Biochem. 57: 369-376.

13. Selye, H、 B. Tuchweber, and L. Bertók. 1966. Effect of lead acetate on susceptibility of rats to bacterial endotoxins. J. Bacteriol 91: 884-890.

14. Buccino, R., J. Lingley, and J. Israel. 1962. Evaluation of the epinephrine skin test as a biological assay for endotoxin. Proc. Soc. Exp. Biol. Med. 110: 724-726.

15. Nowotny, A. 1969. Basic Exercises in Immunochemistry. Springer-Verlag New York, Inc. 185-187.

16. Yin, E. T., C. Galanos, S. Kinsky, R. A. Bradshaw, S. Wessler, O. Lüderitz, and M. E. Sarmiento. 1972. Picogram-sensitive assay for endotoxin: gelatin of Limulus polyphemus blood cell lysate by purified lipopolysaccharide and lipid A from gram-negative bacteria. Biochim. Biophys. Acta. 261: 284-289.

17. Myrvik, Q. N., E. S. Leake, and B. Fariss. 1961. Studies on pulmonary alveolar macrophages from the normal rabbit: a technique to procure them in a high state of purity. J. Immunol. 86: 128-132.

18. Staub, N. C. 1974. Pulmonary edema. Physiol. Rev. 54: $678-811$.

19. van den Brenk, H. A. S., H. Kelly, and M. G. Stone. 1976. Innate and drug-induced resistance to acute lung damage in rats by $\alpha$-naphthylthiourea (ANTU) and related compounds. Br. J. Exp. Pathol. 57: 621-636.

20. Frank, L., D. Woods, and R. J. Roberts. 1977. The effect of diethyldithiocarbamate (DDC) on oxygen toxicity and lung enzyme activity in immature and adult rats. Biochem. Pharmacol. In press.

21. Huber, G., M. La Force, and R. Mason. 1970. Impairment and recovery of pulmonary antibacterial defense mechanisms after oxygen administration. J. Clin. Invest. 49: 47a. (abstr.)

22. Khandwala, A., J. Bernard, and L. Gee. 1973. Linoleic acid hydroperoxide: impaired bacterial uptake by alveolar macrophages, a mechanism of oxidant lung injury. Science (Wash. D. C.). 182: 1364-1365.

23. Drew, R. T., J. Kleinerman, D. Tierney, and R. Owens. 1976. Overview: recent developments in the toxicity of environmental oxidants. Environ. Health Perspect. 16: $157-160$.

24. Turino, G. M., J. R. Rodriguez, L. M. Greenbaum, and I. Mandl. 1974. Mechanisms of pulmonary injury. Am. J. Med. 57: 493-505.

25. Oyanagui, Y. 1976. Inhibition of superoxide anion production in macrophages by anti-inflammatory drugs. Biochem. Pharmacol. 25: 1473-1480.

26. Weinberg, J. B. and J. B. Hibbs, Jr. 1977. Studies on the mechanism of tumor killing by BCG-activated macrophages. Clin. Res. 25: 163A. (Abstr.)

27. Heilman, D. H. 1965. In vitro studies on changes in the reticuloendothelial system of rabbits after an injec- 
tion of endotoxin. (RES). J. Reticuloendothel. Soc. 2: 89-104.

28. Heilman, D. H., and R. C. Bast, Jr. 1967. In vitro assay of endotoxin by the inhibition of macrophage migration. J. Bacteriol. 93: 15-20.

29. Weir, E. K., J. Miczock, J. T. Reeves, and R. F. Grover. 1976. Endotoxin and prevention of hypoxic pulmonary vasoconstriction. J. Lab. Clin. Med. 88: 975-983.

30. Grover, R. F. and J. T. Reeves. 1974. Loss of hyperoxic pulmonary vasoconstriction in dogs given small amounts of endotoxin. Chest 65 (Suppl.): 50S-51S.

31. Cropp, G. J. A. 1965. Effect of high intra-alveolar $\mathrm{O}_{2}$ tensions on pulmonary circulation in perfused lungs of dog. Am. J. Physiol. 208: 130-138.

32. Puy, R. J. M., R. W. Hyde, A. B. Fisher, J. M. Clark, J. Dickson, and C. J. Lambertson. 1968. Alterations in the pulmonary capillary bed during early $\mathrm{O}_{2}$ toxicity in man. J. Appl. Physiol. 24: 537-543.

33. Kistler, G. S., P. R. B. Caldwell, and E. R. Weibel. 1967. Development of lung structural damage to alveolar and capillary lining cells in oxygen-poisoned rat lungs. J. Cell. Biol. 33: 605-628.

34. Smith, G., P. M. Winter, and R. F. Wheelis. 1973. Increased normobaric oxygen tolerance of rabbits following oleic acid-induced lung damage. J. Appl. Physiol. 35: 395-400.

35. Huber, G. L., E. Finder, and F. M. LaForce. 1972. Prevention of oxygen toxicity in the lung. Chest 62: 365 . (Abstr.)

36. Ohlsson, W. T. L. 1947. A study of oxygen toxicity at atmospheric pressure with special references to pathogenesis of pulmonary damage and clinical oxygen therapy. Acta Med. Scand. 190 (Suppl.): 1-93.

37. Bachofen, M., and E. R. Weibel. 1974. Basic pattern of tissue repair in human lungs following unspecific injury. Chest. 65 (Suppl.): 14S-19S.

38. Shtasel, T. F., and L. J. Berry. 1969. Effect of endotoxin and cortisone on synthesis of ribonucleic acid and protein in livers of mice. J. Bacteriol. 97: 1018-1025.

39. Smith, G. L. 1976. Synergistic action of bacterial lipopolysaccharides on serum-stimulated DNA synthesis in mouse embryo fibroblasts. Proc. Soc. Exp. Biol. Med. 153: 187-192.

40. Northway, Jr., W. H., L. Rozeau, R. Petriceks, and K. G. Bensch. 1976. Oxygen toxicity in the newborn lung: reversal of inhibition of DNA synthesis in the mouse. Pediatrics. 57: 41-46. 